\title{
Mammalian Heparanase: Breaking Down Barriers in Tumor Invasion and Metastasis
}

\author{
哺乳動物のヘパラナーゼ：腫瘍の浸潤、転移に必要な障害物の分解
}

Key Words: heparanase, heparan sulfate, heparan sulfate proteoglycan, metastasis, tumor invasion

Heparan sulfate proteoglycans (HSPGs) are ubiquitous macromolecules associated with the cell surface and extracellular matrix of a wide range of animal tissues. HSPGs interact with various growth factors, cytokines, extracellular matrix constituents and enzymes, and are found to be associated with the various biological processes of growth factors and cytokines, as well as being implicated in cell adhesion, recognition, migration and regulation of various enzymic activities. To degrade extracellular HS, various cells such as platelets, leukocytes, endothelial cells and smooth muscle cells express the enzyme heparanase, an endoglycosidase that cleaves HS at a limited number of sites along the polysaccharide chain.

Heparanase activity with cooperative actions of proteases such as matrix metalloproteinases has been long recognized as being essential in the disassembly of the extracellular matrix (ECM) by invading cells. Evidence indicates that heparanase not only assists in the breakdown of ECM but also is involved in the regulation of growth factor activities. Many growth factors are HS-binding and exist in a form of bound HSPG in the ECM. Heparanase activity can liberate HS-binding growth factors from the ECM and make them available for important physiological processes such as angiogenesis and wound healing. Despite this evidence that the heparanase is essential in many biological processes and represents an important target for new drug development, cloning and characterization of the enzyme has remained elusive. Now, identical cDNA sequences of the first mammalian heparanase from human placenta [Vlodavsky, I., Friendmann, Y., Elkin, M., Aingorn, H., Atzmon, R., IshaiMichaeli, R., Bitan, M., Pappo, O., Peretz, T., Michal, I., Spector, L. and Pecker, I. (1999) Nature Medicine, 5, 793-802] and human platelet [Hulett, M.D., Freeman, G., Hamdorf, B.J., Baker, R.T., Harris, M.J. and Parish, C.R. (1999) Nature Medicine, 5, 803-809] have independently been reported, and 50-kDa active recombinant enzymes have been expressed.

Several apparently different heparanase activities have previously been reported. For example, platelets may produce three HS degrading enzymes, with different molecular mass and substrate specificities. However, both papers introduced here report that the DNA sequences encode a unique protein with the ability to cleave HS, and that the identical or highly homologous DNA sequences derived from several other normal and tumor cells undoubtly encode the same heparanase. Although it is possible that splice variants or other structurally distinct genes encode other heparanase, this heparanase may be the domi-
ヘパラン硫酸プロテオグライカン $(\mathrm{HSPG})$ は、広範な動物 組織の細胞表面や細胞外マトリックスに存在する偏在的な高分 子である。HSPG は様々な増殖因子、サイトカイン、細胞外マ トリックス構成分子、酵素類等と相互作用し、増殖因子やサイ トカインの機能活性を制御し、細胞の接着、認識、遊走、そし て様々な酵素類の活性を調節していることが知られている。細 胞外 HS を分解するため、血小板、白血球、内皮細胞、そして 平滑筋細胞などの様々な細胞は、HS 糖鎖中の限られた数の位置 でのみ分解するエンドグルコシダーゼの一種である酵素、ヘパ ラナーゼを発現している。

ヘパラナーゼ活性は、メタロプロテアーゼのようなタンパ

ク質分解酵素と共同して浸潤細胞による細胞外マトリックス $(\mathrm{ECM})$ の分解に重要な役割を果たしていることが長く知られて いた。さらに、へパラナーゼは ECM の分解だけでなく、増殖 因子活性制御にも関わっていることが証明されている。多くの 増殖因子はHS に結合性を持ち、ECMでは HSPG と結合した形 で存在している。ヘパラナーゼの作用で、HS一結合性増殖因子 は ECM から遊離し、血管新生や創傷治癒のような重要な生理 作用のために利用できるようになる。このように、へパラナー ゼは多くの生物学的作用のために不可欠で、新薬開発の重要な 標的となりうる証拠があるにもかかわらず、この酵素のクロー ニングや特性が明らかにされてこなかった。ここで初めて、ヒ トの胎盤から[Vlodavsky, I., Friendmann, Y., Elkin, M., Aingorn, H., Atzmon, R., Ishai-Michaeli, R., Bitan, M., Pappo, O., Peretz, T., Micael, I., Spector, L. and Pecker, I. (1999) Nature Medicine, 5, 793-802]そし てヒト血小板から[Hulett, M.D., Freeman, G., Hamdorf, B.J., Baker, R.T., Harris, M.J. and Parish, C.R. (1999) Nature Medicine, 5, 803809]それぞれ独立的に一致する哺乳類へパラナーゼのcDNA配列 が報告され、その $50 \mathrm{kDa}$ の分子量をもつ活性型組み換え酵素が 発現された。

いくつかの明らかに異なる活性をもつへパラナーゼの存在 が、以前報告されている。たとえば、血小板は分子量や基質特 異性の異なる 3 つの HS 分解酵素を合成している。しかしなが らここで紹介した両方の論文は、その DNA 配列は HS を分解 する独特のタンパク質をコードしている。さらに他のいくつか の正常そして腫瘍細胞由来の一致するあるいは高く相同性をも つ DNA 配列は、疑いなく同じへパラナーゼをコードしている ということができよう。スプライス異性体や他の構造的に異な 
nant enzyme to cleave extracellular HS expressed by mammalian tissues and tumor cells.

Expression of the heparanase gene and protein correlates with the metastatic potential of several human and mouse cell lines. Furthermore, low metastatic murine T-lymphoma and melanoma cells transfected with the heparanase cDNA acquired a highly metastatic phenotype in vivo, reflected by a massive liver and lung colonization. This result provides direct evidence of the important role of heparanase in tumor metastasis. The finding of heparanase activity in the urine of cancer patients is also important, as it may allow the progress of a disease or response to terapy to be assessed.

Heparanase-inhibiting molecules (for example, modified heparin and sulfated polysaccharides) are known to inhibit tumor growth, metastasis, angiogenesis and vascular damage in some experimental models. The availability of large quantities of recombinant enzyme and its characterization are expected to enable the development of better and more selective inhibitors and neutralizing antibodies that will halt the metastatic tumor cells and activated cells of the immune system to leave the circulation and reach their target organs. Thus, the screening of potential inhibitors of heparanase will aid in the development of new anti-metastatic and anti-inflammatory drugs.

\section{Reported by Masayuki Ishihara}

National Defense Medical College, Research Institute, 3-2 Namiki, Tokorozawa, Saitama, 359-8513, Japan

FAX:81-42-991-1611
る遺伝子が他のヘパラナーゼをコードしている可能性はあるけ れども、このへパラナーゼは細胞外 HS を分解する哺乳類の組 織あるいは腫瘍細胞によって発現される主要な酵素であると思 われる。

ヘパラナーゼ遺伝子やタンパク質の発現は、いくつかのヒ トやマウス細胞株の転移性と相関している。さらに、ヘパラ ナーゼ cDNA を導入した低転移性ネズミTーリンパ腫や黒色腫細 胞は高い転移発現型となり、肝臓や肺に多くの転移が観察され た。この結果は、へパリナーゼが腫瘍転移に関して重要な役割 を果たしている直接的な証明にもなる。癌患者の尿中にへパリ ナーゼ活性が現れるという発見もまた重要であり、病気進行や 治療法選択のための診断評価に適用できる可能性がある。

修飾ヘパリンや硫酸化多糖のようなへパラナーゼ活性阻害 分子は、いくつかの実験モデルで腫瘍増殖、転移、血管新生、 血管損傷などを抑制することが知られている。多量の組み換え 酵素が利用と酵素の特性が明らかにされていくと、より良い特 異的な阻害剂や活性中和抗体が開発できるようになり、血中に 入り標的器官に到達する腫瘍細胞の転移や免疫システムでの活 性化細胞の働きを抑制できる。このように、へパラナーゼの阻 害剤をスクリーニングすることは、新しい抗転移そして抗炎症 薬の開発に繋がっていくのでる。

防衛医科大研究センター

石原 雅之 